\title{
Musik Kontemporer dalam Kurikulum dan Buku Sekolah di Jerman
}

\author{
Yudi Sukmayadi ${ }^{1}$
}

Universitas Pendidikan Indonesia, Bandung

\begin{abstract}
ABSTRAK
Tulisan ini menyajikan tentang posisi musik kontemporer dalam kurikulum dan buku sekolah di Jerman. Hal yang dibahas adalah pemilihan materi musik kontemporer untuk setiap kelas, jenis musik kontemporer yang dibahas, serta metode didaktis yang diterapkan. Berdasarkan analisis dapat disimpulkan bahwa melalui pelajaran musik kontemporer, siswa tidak hanya mempelajari hal musikal, namun juga mempelajari masalah kontekstualnya di masyarakat, termasuk di dalamnya masalah musik kontemporer dan perkembangan teknologi.
\end{abstract}

Kata kunci: musik kontemporer, kurikulum, sekolah Jerman

\begin{abstract}
Contemporary Music in German Curriculum and Schoolbooks. This study presents the position of contemporary music in German curriculum and schoolbooks in Germany. This study discusses how to select contemporary music materials for every class, kinds of contemporary music, and how the didactic concepts are applied. This study also discusses how, through contemporary music, the students are introduced to contextual problems in society, including the issue of contemporary music and technology development.
\end{abstract}

Keywords: contemporary music, curriculum, German's school

\section{Pendahuluan}

Di Jerman sebagian besar kebijakan dan peraturan ditetapkan berdasarkan wewenang negara bagian/provinsi masing-masing, tentu saja dengan mengacu pada hal-hal yang bersifat umum dari pemerintah pusat. Kebijakan tersebut termasuk di dalamnya pengaturan penyelenggaraan bidang pendidikan sejak jenjang pendidikan usia dini/ dasar sampai dengan universitas/sekolah tinggi. Dengan penetapan kebijakan yang berbeda di masing-masing provinsi, maka terdapat keunikan tersendiri, di mana penetapan kebijakan berbasis pada potensi provinsi tersebut. Salah satu misalnya desain kurikulum musik dan penetapan buku-buku pelajaran musik yang dilakukan secara mandiri di masing-masing provinsi.

Posisi musik kontemporer pada kurikulum pendidikan musik untuk tingkat Gymnasium (setingkat mulai SD Kelas V, SMP, dan SMA) di provinsi Sachsen-Anhalt, misalnya berisi pembagian beberapa tema pembelajaran. Tematema spesifik tersebut biasanya terdiri atas lima sampai dengan tujuh tema. Untuk memberikan kemudahan bagi para guru dalam menginterpretasi kurikulum ini, maka diberikan beberapa tujuan pembelajaran yang ingin dicapai dari proses pembelajaran musik. Setelah itu terdapat pula dua hal yang dianggap penting dalam struktur kurikulum ini, yakni penjabaran tema-tema melalui isi kegiatan pembelajaran yang lebih spesifik dan berbagai arahan mengenai proses pembelajaran yang sebaiknya dilakukan dalam pelajaran musik.

Oleh karena pelajaran mengenai musik kontemporer tidak selalu disebut secara spesifik, maka penulis memilih tema-tema pelajaran yang bisa berhubungan langsung dengan aspek musik kontemporer, misalnya sebuah gambaran kegiatan

\footnotetext{
Alamat korespondensi: Departemen Pendidikan Seni Musik FPSD UPI, Jln. Dr. Setiabudhi No. 229 Bandung. Hp: 081931341837. E-mail: yudi.sukmayadi@upi.edu
} 
membuat komposisi oleh seorang komponis atau hal-hal spesifik lainnya yang berhubungan dengan aspek-aspek dasar pembentukan musikalitas siswa.

Tema-tema pembelajaran yang dipilih dan dianggap bisa berhubungan dengan musik kontemporer tersebut adalah: Umgang mit Stimme und Instrumenten (Penggunaan Bunyi Vokal dan Instrumen), Musik der Gegenwart (Musik Masa Kini), dan Musik und Programm (Musik dan Program). Di kelas V dan VI ketiga tema tersebut menawarkan kegiatan pembelajaran yang bertujuan untuk membentuk dasar-dasar kompetensi musikal siswa. Proses pembelajaran tema-tema tersebut, di kelas VII, VIII, dan IX lebih mengarah kepada kegiatan aplikasi prinsip-prinsip dasar musikal melalui pengalaman bermusik melalui tema-tema yang dibahas tersebut.

\section{Tema Pembelajaran Musik Kontemporer pada Kelas V dan VI}

Tema Umgang mit Stimme und Instrumenten (Penggunaan Bunyi Vokal dan Instrumen) dianggap bisa dilakukan untuk melatih landasan sensitivitas siswa terhadap bunyi-bunyian. Pada tema ini siswa diharapkan dapat mengenal cara membuat dan mengetahui fungsi alat musik serta alat yang bisa menjadi alat musik, yaitu setiap benda yang hakikatnya bisa berbunyi. Kegiatan yang dilakukan adalah membuat instrumen sendiri secara sederhana dan mencoba untuk memainkannya. Penulis berpendapat bahwa kegiatan dasar ini bisa lebih menguntungkan siswa untuk meletakkan dasardasar sensitivitas terhadap bunyi, dengan alasan bahwa pada saat ini belum terdapat batasan-batasan yang menghalangi kreativitasnya. Bisa saja dalam pelaksanaan kegiatannya, siswa bermain bunyi melalui bahan-bahan sederhana yang terdapat di lingkungan sekitar untuk kemudian dimodifikasi menjadi alat musik ciptaannya sendiri.

Melalui tema pembelajaran di atas, siswa bisa mengenal karakteristik bahan-bahan dasar alat musik dan karakteristik bunyi yang dihasilkan jika alat musik tersebut dimainkan. Siswa pun bisa bereksperimen untuk membuat semacam perbandingan bunyi-bunyi dengan mengolah bahan-bahan dasar alat musik dari kayu, gelas, metal, dawai, dan bahan lainnya. Dari pembelajaran ini siswa bisa menemukan riwayat mengenai bunyibunyian dan membuat katalog mengenai bahan, sumber, dan jenis bunyi-bunyian. Konsep semacam ini misalnya bisa bermanfaat di Indonesia. Hal pertama adalah bahwa sarana dan prasarana dalam pelajaran musik di Indonesia, utamanya perlengkapan alat-alat musik masih belum memadai, sehingga dengan tema-tema pelajaran tersebut bisa menjadi salah satu alternatif untuk mengatasi masalah ketidaktersediaan alat musik di kelas. Hal kedua adalah bahwa sebagian besar siswa masih belum begitu sering dikenalkan pada kegiatan praktik musik secara langsung. Biasanya mereka hanya mengenal dan menyukai jenis-jenis musik yang mereka dapati dari kehidupan seharihari. Oleh sebab itu, melalui kegiatan praktik musikal mengenai pembahasan materi dasar tentang karakter bunyi yang netral tersebut, bisa membekali mereka mengenai prinsip dan karakter bunyi di dalam musik. Hal inilah yang diperlukan dalam kegiatan membangun kompetensi musikal secara umum.

Tema Musik der Gegenwart (Musik Masa Kini) adalah tema yang membahas secara konkrit mengenai musik kontemporer dengan materi utama hal-hal praktis mengenai pengenalan prinsip teknik komposisi dalam musik kontemporer. Hal-hal yang menarik untuk diadaptasi kepada situasi Indonesia antara lain mengenai kerjasama dengan para komponis di dalam kelas. Selama ini kegiatan tersebut belum begitu banyak dilakukan di Indonesia, padahal kegiatan ini bisa memberikan peluang lebih banyak kepada siswa untuk bisa langsung berinteraksi musikal dengan menimba pengalaman berkarya para komponis. Selain itu kegiatan siswa mengunjungi pergelaran-pergelaran bisa memperdalam pengalaman musikal secara langsung. Apa yang diajarkan guru di kelas, bisa diperdalam dalam kegiatan praktik apresiasi musik melalui kunjungan pergelaran tersebut.

Tema Musik und Programm (Musik dan Program) bertujuan untuk mengenalkan kepada siswa suatu kejadian atau peristiwa yang bisa diterjemahkan (didukung, diperkuat) melalui aneka bunyi-bunyian. Kegiatan ini bisa berupa penataan berbagai karakter bunyi-bunyian dari 
berbagai alat musik buatan sendiri, suara, dan disertai gerakan tubuh untuk menerjemahkan suatu cerita. Dalam kegiatan musikal ini siswa mendapat peluang untuk mengolah kepekaan auditifnya, menguraikan arti dan karakter suatu bunyi, dan mengolah kemampuan untuk menata berbagai karakter bunyi yang berbeda hingga menjadi satu "komposisi" yang mengolah kesatuan waktu melalui bunyi. Upaya penerjemahan peristiwa atau cerita-cerita ke dalam komposisi bunyi-bunyian ini bisa ditindaklanjuti lebih jauh lagi dengan pengenalan simbol-simbol notasi.

\section{Tema Pembelajaran Musik Kontemporer pada Kelas VII dan VIII}

Pada kelas VII dan VIII tema Umgang mit Stimme und Instrumenten (Penggunaan Bunyi Vokal dan Instrumen) diperluas wilayah pembahasannya untuk mencapai tujuan agar siswa mengenal dan melatih berbagai kemungkinan mendesain suara pada saat bernyanyi dan berbicara. Isi pembelajaran berupa kegiatan eksperimen membuat musik yang memanfaatkan media suara mulut. Teknik pembuatannya misalnya dengan melalui pengolahan berbagai macam perbedaan gaya dan karakter berbicara, membuat gaya berbicara dengan ritme-ritme tertentu (gaya berbicara ritmis), menerapkan teknik kanon dan rap dalam gaya bicara.

Tema tersebut cukup sederhana dan menurut penulis bisa dimanfaatkan untuk mengenalkan prinsip dasar pengolahan komposisi bunyi-bunyi melalui bunyi mulut kepada siswa. Kegiatan dasar ini bisa berupa latihan kepekaan musikal siswa untuk mengolah warna bunyi dalam bentuk kegiatan berbicara yang musikal. Tentu saja dalam kegiatan tema pembelajaran ini, kegiatan eskplorasi gaya berbicara bisa dikombinasikan dengan prinsip-prinsip dasar musik, misalnya berbicara dengan kalimat tinggi-rendah nada yang berbeda, gaya berbicara yang silih berganti antara tempo cepat-lambat dalam pengolahan bunyinya, dinamika berbicara dalam gaya keras-lembut, dan mengolah variasi ritme berbicara. Hal ini bisa menjadi pengolahan komposisi gaya berbicara melalui media bunyi mulut.
Tema Musik der Gegenwart (Musik Masa Kini) pada kelas VII dan VIII membahas berbagai adaptasi musik dari berbagai model gaya musik sebelumnya. Topik-topik pembelajarannya yakni: adaptasi berbagai gaya musik, instrumentasi baru, mengenal musik baru yang berdasarkan pada karya-karya, dan bentuk model musik dari abad sebelumnya. Musik baru, terutama musik baru yang dicipta setelah tahun 1950-an merupakan musik gaya individual dari masing-masing komponis. Pada tema ini, topik yang diperdalam adalah musik baru hasil perluasan/ perkembangan dari musik tradisional yang diolah makin individual. Komponis secara individual dan bertanggung jawab untuk menemukan dan memperluas gramatika musiknya sendiri. Hal ini secara tidak langsung dapat memperluas aturanaturan musik yang sudah ada sebelumnya. Maka, karya-karya musik tradisional bisa merupakan referensi saja. Ciri khas dan elemen dasar musiknya bisa kemudian menjadi bahan ide-ide baru bagi para komponis dalam membuat sebuah komposisi musik baru. Jika terdapat kemiripan dengan musik masa sebelumnya, maka hal ini bukan merupakan suatu hasil dari upaya adaptasi. Tema adaptasi berbagai model gaya ini kemudian bisa dibahas lebih lanjut, khususnya dalam bidang aliran musik populer, terutama karya-karya musik populer baru yang dicipta masa kini.

Tema Musik und Programm (Musik dan Program) pada kelas VII dan VIII menitikberatkan pada kegiatan praktik bermusik yang berorientasi pada cerita dan gambar. Topik-topik pembelajarannya adalah membuat semacam kumpulan karakter bunyi dari tema kehidupan keseharian, penerjemahan gambar, termasuk dari kumpulan teks literatur ke dalam wujud bunyi. Kegiatan yang dapat dilakukan dalam pembelajarannya antara lain: konsepsi dan kegiatan realisasi sebuah perwujudan bunyi-bunyian melalui praktik bermusik, menotasikan wujud bunyi ke dalam notasi grafis, membuat komposisi bunyi dari contoh tema-tema keseharian, misalnya: perjalanan menuju sekolah, pada pagi hari, berlibur, atau berdasarkan sajak-sajak yang sudah ada, dan membuat komposisi dari berbagai gambar atau foto. Tema ini bisa dianggap penting sebagai landasan untuk membangun minat siswa dalam 
bidang komposisi musik baru. Melalui tawaran kegiatan penciptaan komposisi musik sederhana melalui alat media cerita dan gambar ini, siswa bisa mendapat peluang untuk mengolah kepekaan musikal mengenai bunyi dan konotasinya.

\section{Tema Pembelajaran Musik Kontemporer pada Kelas IX sampai XII}

Tema Umgang mit Stimme und Instrumenten (Penggunaan Bunyi Vokal dan Instrumen) pada kelas IX bertujuan untuk mengembangkan lebih luas dari tema yang sama di kelas V dan VI serta VII dan VIII. Topik improvisasi dan aransemen menjadi topik inti dalam kegiatan pembelajarannya. Tema kesatu di kelas VII dan VIII mengenai komposisi dengan gaya berbicara bisa diperdalam lebih lanjut di kelas IX ini, hanya saja kegiatannya bisa fokus kepada salah satu jenis komposisi. Sebagai contoh melalui komposisi Die Landschaft in meiner Stimme (Klaus-Hinrich Stahmer), siswa diarahkan untuk mengembangkan kegiatan eksperimen suara yang dipadu dengan pembahasan mengenai simbolsimbol bunyinya.

Tema Musik der Gegenwart (Musik Masa Kini) pada kelas IX membahas lebih spesifik materi musik kontemporer. Melalui pemilihan contoh-contoh musik kontemporer, siswa diharapkan bisa mengenal struktur dan karakteristik musiknya, mampu menjelaskannya hingga bisa menerapkan prinsip struktur dan karakteristik musik tersebut dalam kegiatan penciptaan karya musik versi sendiri. Beberapa kegiatan yang ditawarkan dalam proses pembelajarannya antara lain: notasi grafis, menerapkan prinsip komposisi musik tradisional, memilih contoh-contoh musik: teknik musik dodekafoni, musik serial, aleatorik, teknik cluster, musik elektronik dan musik minimalis (dan sebenarnya mungkin masih terdapat banyak jenis musik yang lain lagi yang belum disebut dalam kurikulum, namun barangkali lebih menarik, misalnya jenis komposisi-komposisi baru yang dicipta komponis masa kini). Kegiatan pokok pelajaran musik kontemporer di kelas IX ini lebih mengutamakan aspek apresiasi beberapa karya musik kontemporer yang sudah baku dan sudah terkategorikan pada urutan perkembangan sejarah musik.
Pada Einführungsphase (Tahap Implementasi) di kelas X, tema-tema pelajaran yang terkait dengan musik kontemporer lebih mengedepankan aspek pengembangan wawasan kognitif yang diambil dari pengalaman praktis di kelas-kelas sebelumnya. Wawasan kognitif ini lebih bersifat pengembangan wawasan dalam bentuk karya tulis mengenai musik kontemporer yang dilatih ke dalam kemampuan menulis kritis. Hal ini cukup penting agar siswa bisa mewujudkan hasil apresiasinya terhadap perkembangan musik masa kini dalam bentuk tulisan. Siswa bisa bertukar argumentasi mengenai musik kontemporer termasuk analisa komposisinya. Namun demikian, pada tahapan ini tidak salah jika siswa diberikan kesempatan untuk menulis (mencipta) karya musik kontemporer sendiri, jika mereka berminat. Justru pada tahapan inilah siswa secara mandiri bisa menyimpulkan berbagai gaya musik kontemporer yang telah dipelajari ke dalam bentuk gaya musiknya sendiri yang mandiri. Nampaknya inilah upaya konkrit untuk mengenalkan cara kerja komponis dalam menulis komposisi baru.

Tema-tema pelajaran yang terdapat di kelas $\mathrm{X}$ sampai XII memiliki tujuan antara lain: 1) Siswa bisa mempelajari kembali apa yang sudah dipelajari di kelas sebelumnya, secara bertahap mempelajarinya ke dalam struktur ilmiah dan kesenimanan yang lebih kompleks, dan siswa memiliki potensi teruji di bidangnya; 2) Siswa mampu mengolah secara mandiri terhadap contoh-contoh musikalitas dalam kekaryaan, dan mengembangkan hal-hal dasar pekerjaan ahli musik; dan 3) Siswa mendapatkan pengalaman tentang perkembangan musik Eropa sebagai dasar untuk mendalami tema-tema dalam tahapan kualifikasi.

Tujuan di atas, diterjemahkan ke dalam tema Auf der Suche nach den Wurzeln abendländischer Musik (Upaya Mencari Akar-akar Musik Barat), dengan berorientasi pada isi materi "Pencarian Jejak Musikalis“. Hal lain yang harus diperhatikan dalam pembelajaran ini adalah mengenalkan format komposisi dan prinsip-prinsip musik tradisi dalam karya abad ke-20 dan ke-21, misalnya pada karya "Carmina Burana" (Carl Orff).

Dalam kerangka tema Zeitzeugen - Vielfalt in der Musik des 20. Jahrhunderts (Saksi-saksi - 
Keragaman dalam Musik Abad ke-20) pada kelas XI dan XII, dibahas mengenai hal-hal baru di dalam musik kaitannya dengan perkembangan teknologi. Materi yang disajikan adalah mengenai prinsipprinsip aturan baru dan teknik-teknik komposisi. Hal-hal yang harus dikenalkan kepada siswa mengenai latar belakang historis melalui tematema: liberalisasi masyarakat dan kesenian abad ke20 di Jerman, teknik pusat bunyi, dodekafon dan teknik-teknik musik serial, dan kekhasan musik pada periode gaya-gaya tertentu (cluster, aleatorik, futurisme, fluxus, teknik-tekik eksperimental sebagai ekspresi individual di dalam musik/seni, neoklasisme sebagai aliran baru, dan praktik musik/ aplikasi teknik-teknik yang dipilih).

Materi lain yang dipelajari adalah mengenai "Musik dan Teknik" dengan pembahasan mengenai perkembangan radio, alat rekam, televisi dan manfaatnya dalam perkembangan abad ke-20, instrumen-instrumen baru: instrumen-instrumen elektronik, synthesizer, komputer, dan gaya-gaya komposisi hubunganannya dengan revolusi teknik: musik elektronik, musik konkrit, musik film, dan techno.

\section{Tawaran Didaktik dan Musik Pendidikan dalam Buku Sekolah}

Seperti yang sudah dikemukakan pada awal, bahwa masing-masing provinsi di Jerman memiliki kewenangan menetapkan berbagai kebijakan menyangkut penyelenggaraan pelajaran musik. Hal ini juga berlaku dalam proses penentuan buku pelajaran musik yang bisa digunakan di sekolah. Oleh sebab itu di masing-masing provinsi memiliki komisi penilai kelayakan isi buku. Salah satu tugasnya adalah mengkaji sejauh mana aspekaspek didaktis dikembangkan dalam setiap buku. Namun demikian, perlu dipahami bahwa dalam pelaksanaannya guru diberikan keleluasaan untuk menggunakan semua sumber buku yang ada. Pada bagian ini, dibahas aspek-aspek didaktis yang dikembangkan dalam setiap buku pelajaran musik. Adapun buku-buku pelajaran musik dari Jerman yang diteliti adalah: Musik um uns 2/3, Spielpläne 2, Spielpläne 7/8, Dreiklang 9/10, dan Musix.

Buku Musik um uns 2/3 mengawali pembahasan tema "Minimal Music" dengan penjelasan sangat singkat mengenai riwayat Steve Reich (1936). Suatu saat dia menggunakan dua alat rekam untuk membuat komposisi kanon. Reich merekam satu motif kanon yang ia buat, kemudian hasil rekamannya tersebut diputar ulang pada dua alat rekam pada saat yang sama. Secara kebetulan, meski permainan dimulai pada saat bersamaan, tapi dengan perubahan sedikit tempo, maka seolah-olah salah satu motif kanon tersebut lambat laun keluar dari uni-sono-nya. Ide ini ia terapkan dalam karya "Piano phase for two pianists". Cara permainan karyanya adalah pianis pertama memainkan figur pendek seperenambelas sebanyak $4-8$ kali, kemudian diikuti oleh pianis kedua, sampai kedua pianis memainkan figur tersebut secara unisono dan diulang $12-18$ kali. Kemudian pianis kedua mempercepat tempo permainannya, sehingga setelah diulang 16 - 24 kali figur yang sama dari seperenambelas tersebut terdengar semakin ke belakang. Permainan diulang terus menerus sampai permainan figurasi kembali sama. Uraian proses permainan seperti ini kemudian bisa dikategorikan sebagai salah satu teknik komposisi dalam musik minimalis.

Proses penulisan komposisi musik minimalis di atas sebenarnya tidak semudah yang digambarkan dalam proses saat Steve Reich menemukan prinsip komposisi musik minimalis tersebut melalui alat rekaman. Tetapi secara utuh, struktur komposisinya sendiri tak lepas dari pengolahan bunyi-bunyi itu tersendiri. Artinya, kesatuan antara teknik komposisi yang digunakan tidak lepas dari pertimbangan mengolah bunyi dan waktu. Hal ini misalnya bisa diwujudkan melalui aplikasi hasil penemuan Reich dalam kegiatan siswa sebagai salah satu tawaran didaktis. Bentuk tawaran kegiatan didaktis yang diuraikan dalam buku tersebut adalah: 1) mendengar contoh awal karya; 2) memainkan urutan nada $c^{c}-e^{c}-a^{c}-g^{c}$ selama tiga menit dalam tempo $\mathrm{MM}=60$ pada piano dan merekamnya; 3) merekam ulang hasil rekaman tersebut; 4) memutar ulang hasil kedua rekaman tersebut bersamaan; serta 5) menganalisis apa yang terjadi. Kegiatan praktik siswa melalui alat rekam ini bisa bermanfaat untuk mengalami langsung fenomena musikal dalam komposisi musik minimalis. 
Buku Spielpläne 2 menulis hal menarik tentang tema 'Grafik zum Spielen' (Grafik untuk Bermain). Walaupun pemaparannya cukup singkat tapi isinya cukup bermakna. Pada awal sudah disajikan dua macam contoh notasi grafis dari Helmut W. Erdmann (1947) dan Earl Brown (1926-2002). Notasi grafis tersebut dapat bermakna sebagai tinggi-rendah nada, panjang-pendeknya nada atau keras-lembutnya nada. Selain itu disajikan pula gambar dari Pablo Picasso (1881-1973): 'Das Gesicht des Friedens' (Wajah Kedamaian). Kemudian ditulis empat hal kegiatan yang didaktis untuk siswa: 1) mencipta musik berdasarkan gambar-gambar tersebut; 2) menggunakan instrumen musik dan suara, menentukan arti musikalitas dari gambar Erdman dan Brown, serta mendiskusikan bagaimana penerjemaahan simbol-simbol gambarnya ke dalam bahasa bunyi; 3) membandingkan hasil karya siswa dengan rekaman yang sudah ada; dan 4) memahami pesan dari gambar Picasso dan menerjemahkannya ke dalam bahasa musik. Hal ini bermanfaat untuk membangun musikalitas dalam mendiferensiasikan karakter bunyi yang bisa menjadi landasan untuk proses mencipta karya musik. Hal didaktis ini bisa bermanfaat untuk sekolah di Indonesia, karena selama ini siswa seolah-olah hanya menerima materi pelajaran dari guru saja sehingga siswa kurang memiliki kebebasan untuk mengungkapkan kreativitasnya di kelas.

Tema selanjutnya adalah 'Neues vom Klavier' (Hal-hal baru dari Piano) melalui pembahasan karya John Cage (1912-1992): 'Sonata V for Prepared Piano'. Pada bagian awal, uraian materi disajikan dengan potongan partitur dan tulisan pendek mengenai upaya Cowell (1897-1965) dan muridnya Cage (1912-1992) dalam mencari kemungkinan bunyi dan teknik permainan baru pada istrumen Piano. Melalui karya 'Aeolian Harp' (1923) Cowell ingin memperkenalkan bunyi-bunyi harpa yang dibawakan dari alunan udara. Sedangkan Cage diceritakan menggunakan Baud, kuku, dan karet yang menutup celah antara kawat-kawat piano untuk karyanya. Kegiatan didaktis yang ditawarkan kepada siswa adalah: 1) mendengarkan karya yang tidak biasa dari Cowell dan Cage ini, dan 2) mencoba memainkan salah satu bagian dari karya tersebut. Kegiatan didaktis ini bermaksud untuk menjelaskan upaya komponis dalam mencari kemungkinan bunyi-bunyi baru dan teknik permainan yang baru untuk alat piano. Melalui karya "Prepared Piano" ini siswa dikenalkan untuk memahami proses eksplorasi bunyi yang tidak lazim melalui berbagai teknik menutup celah antara masing-masing kawat. Hal ini bisa dilakukan, misalnya siswa memainkan berbagai motif ritme tertentu dari karya tersebut dengan dua teknik yang berbeda yaitu dengan bunyi piano yang sebenarnya, dan bunyi piano yang antara kawatnya dibungkam. Kemudian siswa bisa diajak untuk mendiskusikan perbedaan karakter dari keduanya.

Tema lain yakni 'Neues von und mit der Stimme' (Hal-hal Baru dari dan dengan Bunyi) melalui karya Luciano Berio (1925-2003) 'Sequenza III für Frauenstimme'. Bagian ini diuraikan dalam sistematika tulisan 'Sprachegenauer betrachtet' (Bahasa - Diperhatikan dengan jeli) yang dijelaskan cukup rinci tentang apa yang disebut kerangka kata dan kalimat serta arti dan maksudnya, di mana setiap kalimat mengandung pesan. Kemudian disajikan potongan partitur dari karya 'Sequenza III' dan riwayat sangat singkat mengenai Berio berikut penjelasan karyanya. 'Sequenza III' yang teksnya diambil dari puisi karya Markus Kutter ini, dimaksud oleh Berio sebagai hasil usaha melalui pengembangan berbagai kemungkinan ungkapan suara. Selain ini dipilih pula contoh karya 'Artikulation' dari György Ligeti (1923-2006). Partitur ini belum pernah diterbitkan dan hanya ada tulisan secara teknis saja, maka tidak ada sajian potongan partitur dari Ligeti dalam buku ini, melainkan uraian riwayat hidupnya secara singkat saja. Selanjutnya adalah penjelasan singkat mengenai karya 'Artikulation'. Kegiatan didaktis yang ditawarkan kepada siswa adalah: 1) menerjemahkan aturan permainan dari bahasa Inggris; 2) mencoba memahami antara aturan permainan dan simbol-simbol notasi serta bagaimana simbol-simbol tersebut dimainkan melalui suara; 3) mendengarkan contoh musik sambil membaca notasinya; 4) mendengarkan keseluruhan karya 'Sequenza III' dan memperkirakan maksud Berio menulis karya 
ini; 5) menuliskan situasi pembicaraan pada saat mendengarkan; 6) menuliskan persamaan dan perbedaan dari kedua komponis tersebut; serta 7) menuliskan perbedaan situasi pendengaran di panggung yang menyajikan musik elektronik dengan menggunakan pengeras suara dan konser di mana ada pemusik di podium.

Tema 'Farben - Klangfarben' (Warna - warna bunyi) dibahas melalui komponis Arnold Schönberg (1874-1951). Pada bahasannya dijelaskan antara lain bahwa Schönberg bereksperimen dengan warna dan cahaya agar pengaruh kepada musiknya bisa diperkuat. Setidaknya peristiwa ini disejajarkan dalam masa kekaryaan Schönberg. Uraian selanjutnya adalah penyajian gambar dari Franz Marc (1880-1916): 'Pferde und Adler' (1913). Kegiatan didaktis yang ditawarkan kepada siswa adalah: 1) menggambar figur yang sama dengan berbagai perbedaan warna dan mendengarkan satu akord dalam perbedaan Klangfarben dan menjelaskan efeknya; 2) menjelaskan gambar dari Franz Marc, ungkapan pemilihan warna dan keseluruhan komposisi warnanya; dan 3) saling melengkapi antara telinga dan mata dalam tema bunyi dan warna. Selanjutnya disajikan potongan partitur 'Farben' (Warna-warna) bagian tiga dari siklus lima Orchesterstücke op. 16 dari Schönberg berikut analisa pendek mengenai musiknya. Kegiatan didaktis yang ditawarkan: 1) mendengarkan karya "Farben" dari Schönberg; 2) siswa memahami dengan baik karya-karya Schönberg, jika siswa akan membuat sendiri karya yang sejenis; dan 3) berdasarkan pengalaman, maka siswa sebaiknya memahami cara komponis senior berkarya dengan warna bunyi. Hal didaktis ini bermanfaat karena siswa bisa mengalami langsung musiknya dalam proses penciptaan musik sendiri. Namun demikian, hal-hal mendasar yang perlu mendapat perhatian adalah bagaimana warna bunyi bisa dihasilkan melalui kreativitas siswa dalam bentuk ekspresi bunyi lainnya. Sementara ini perbedaan warna bunyi yang dipahami dari karya 'Farben' (no. 3 dari 5 Orchesterstücke op. 16) ini betul-betul berorientasi pada perbedaan pengolahan masing-masing akor. Lebih menarik lagi apabila Klangfarben dalam karya siswa sendiri, pemahamannya bisa lebih luas lagi dan tidak hanya fokus pada pengolahan akor saja, melainkan sebagai hasil dari pengolahan warna suara dari berbagai peralatan yang ada.

Tema 'Konstruktion und Freiheit' (Konstruksi dan Kebebasan) dengan fokus kepada komponis Olivier Messiaen (1908-1992) diawali dengan bahasan mengenai salah satu pekerjaan Messiaen, yakni ketertarikannya terhadap Ornithologie (Erforschung der Vogelarten/Meneliti Jenis-jenis Burung). Dalam potongan partitur 'Livre d'orgue IV: Chants d'oiseaux' (1951) digambarkan berbagai karakter bunyi macam-macam burung. Tawaran kegiatan ini penting untuk dipelajari di kelas yakni mendengarkan bunyi burung yang asli dan membandingkannya dengan jenis-jenis suara burung dalam komposisi Messiaen. Kegiatan ini cukup menarik sebagai uji coba pemanfaatan bunyi-bunyi alam ke dalam sebuah komposisi musik. Dengan tawaran ini diharapkan siswa dapat memahami karakter bunyi-bunyi dari alam. Kemudian, melalui katalog bunyi yang dihasilkan, siswa sendiri bisa memanfaatkannya sebagai alat bantu menyusun bunyi-bunyian menjadi karya mandiri.

Buku Spielpläne 7/8 menyoroti tema 'Experimentieren mit Klängen: Phasen’ (Eksperimen-eksperimen dengan Bunyi: Fase-fase tertentu). Uraiannya langsung membahas karya melalui potongan partitur berupa simbol-simbol bunyi, angka-angka dan termasuk di dalamnya petunjuk permainan. Buku ini lebih cenderung menawarkan kegiatan memainkan masing-masing karyanya. Langkah ini bisa ditempuh dan bisa memberikan manfaat tertentu bagi siswa. Alasannya adalah aspek didaktis yang ditawarkan tidak sekedar memainkan saja, tetapi di antara kegiatan memainkan tersebut terdapat aspek yang cukup bagus untuk membangun kompetensi musikal siswa dan memberikan kegiatan siswa berpikir dalam rangka menginterpretasi notasinya. Tawaran didaktis tersebut misalnya cara membunyikan masing-masing bagian dan penunjuk bunyi yang akan digunakan.

Dalam buku Dreiklang 9/10 terdapat tema 'Minimal Music' dengan bahasan komposisi 'Phase Patterns' (1970) dari Steve Reich (1936). Uraian diawali dengan bahasan potongan partitur karya tersebut berikut penjelasan singkat latar 
belakang karyanya. Tidak ada usulan didaktis yang cukup memberikan pengalaman baru bagi siswa. Kegiatan yang ditawarkan utamanya adalah hanya memainkan partitur karya tersebut dan prinsip saling bersahutan oleh karena permainan pattern-nya. Selain ini terdapat tema 'SchulMusik - Ein Klang-Projekt' (Musik Sekolah - Sebuah Proyek Bunyi). Yang menarik adalah pada tema ini siswa sudah diarahkan pada kegiatan praktek langsung bermusik. Mereka tidak dibebani dengan kriteria yang menuju pada salah satu aliran musik kontemporer yang ada. Sudah pada awal disajikan satu pernyataan yang cukup menarik, yaitu siswa dapat mengisi sekolah dengan bunyi, mengalami sekolah tersebut sebagai ruangan bunyi, dan dari beberapa titik yang berbeda menghiasinya dengan lampu yang bercahaya. Ini satu pernyataan yang secara pedagogis bisa mengarahkan pengalaman siswa dari sesuatu yang netral dan menjadikanya sebagai sesuatu hal baru versi siswa.

Kegiatan didaktis selanjutnya adalah siswa diarahkan untuk dibagi ke dalam dua kelompok. Kelompok I (Raumklänge/Bunyi-bunyi Ruangan) dengan dua usulan kegiatan; 1) konsentrasi mendengar selama 20-30 detik terhadap semua bunyi dari dalam dan luar kelas sambil menutup mata, kemudian menyortir bunyi-bunyi tersebut dan berkonsentrasi kepada salah satunya saja, seterusnya mencari bunyi yang lainnya yang bisa berkompromi dengan bunyi yang satu tadi, dan mengingat terus kejadian tersebut; 2) Klangprotokoll (Catatan Bunyi), selama 30-120 detik mencatat bunyi-bunyi, menyimpan ingatan dari percobaan kegiatan pertama, kemudian mencoba menuliskan bunyi yang didengar tadi ke dalam notasi). Di sini ditawarkan beberapa usulan notasi (ada yang berbentuk notasi balok, gambar wujud bunyi asal, dan hanya berupa simbol-simbol saja; 3) Kompositorische Berarbeitung (Penggubahan Kompositoris), dengan saling menukar catatan bunyi, saling memainkan notasi dengan percobaan oleh berbagai instrumen, memperbaiki struktur notasi, dan merekam karya untuk membandingkan dengan realitas bunyi aslinya pada kegiatan awal.

Kelompok II (Klangräume/Ruang-ruang Bunyi), dengan usulan kegiatan: menentukan titik-titik tempat di sekitar sekolah dengan berbagai bunyi-bunyi ruang, misalnya di tangga, ruang bawah tanah, aula, pintu masuk, dan kemudian membuat catatan bunyi dan partitur bunyi, membuat 'Klang-Happening' (happening bunyi) dan menjadikannya sebagai bagian dari konser sekolah. Kegiatan ini berfungsi sebagai kegiatan dasar musikal dan netral untuk siswa. Dalam kegiatan tersebut memungkinkan siswa belajar mengenai prinsip bunyi dan kepekaannya terhadap bunyi yang berangkat dari lingkungan sekitarnya. Pengalaman ini akan memberkas dan didapati ulang ketika mereka dihadapkan pada pekerjaan memilah-milah bunyi dari alat musik untuk komposisi baru. Hal ini sejalan dengan proses kreatif seniman dalam menggarap, di mana ada satu tahapan yang dilakukan antara lain melalui proses eksplorasi maupun improvisasi hingga membentuk satu komposisi (Warsana, 2012: 81).

Selanjutnya terdapat tema 'Der Zufall als Prinzip' (Prinsip Kebetulan) dengan pembahasan Komponis John Cage (1912-1992) yang dimulai dengan pembahasan singkat mengenai prinsip karya 4'33" serta 'Radiomusic'. Hal ini menunjukkan bahwa aspek memainkan karya Cage lebih diutamakan. Di sana terdapat potongan petunjuk untuk memainkan partitur 'Radiomusic', beserta usulan langkah-langkah memainkannya untuk siswa. Untuk tema 'Musik für Vokalisten' (Musik untuk Vokalis-vokalis) terdapat pembahasan karya '... geträumt (untuk 36 penyanyi)' dari Adriana Hölszky (1953). Pemilihan karya sebagai subjek dalam pembahasan tema ini dianggap sudah cukup tepat. Selain ini dalam konteks perkembangan musik kontemporer, karya ini merupakan karya baru dan nampaknya belum terkategori dalam sejarah perkembangan musik kontemporer itu sendiri. Ide garamatika musiknya bisa dianggap betul-betul individual.

Berdasarkan penelaahan terhadap sejumlah buku pelajaran musik di sekolah di atas, sebagian besar contoh musik kontemporer yang dibahas adalah jenis-jenis musik kontemporer yang sudah terkategorikan sebagai salah satu jenis musik dalam sejarah perkembangan musik di Eropa. Musik kontemporer tersebut hanya dipilih menurut teknik-teknik komposisi tertentu dan relevansinya dengan perkembangan musik kontemporer pada 
saat ini semakin berkurang oleh karena justru seolah-olah sudah masuk warisan musik tradisi Eropa. Karya dari Cage misalnya (melalui teknik Zufall) sering sekali menjadi topik bahasan di dalam buku tersebut.

Dengan demikian, sebaiknya tidak salah kalau terdapat pembahasan musik kontemporer dari komponis masa kini dan yang karyanya ditulis mulai tahun 80an, 90an atau 2000an. Alasannya adalah bahwa oleh karena fenomena karyanya lebih luas dan teknik komposisi yang digunakan sendiri lebih individual dan belum terkategorikan dalam sejarah musik, melainkan seolah-olah sedang mencari orientasi-orientasi baru. Hal ini bisa sekaligus menjadi tawaran mengenai wawasan baru untuk mengkategorikan lagi teknik-teknik komposisi yang digarap komponis masa kini.

Dari buku-buku yang ditelaah, hanya terdapat satu nama komponis masa kini yang sudah dimulai dibahas, yakni Adriana Hölszky. Namun demikian dalam salah satu buku baru 'Musix' yang terbit Maret 2011 dari Helbling Verlag terdapat satu tema mengenai bahasan komponis masa kini. Tema tersebut adalah ' $\mathrm{Zu}$ Besuch beim Komponisten Dieter Mack' (Kunjungan kepada komponis Dieter Mack). Tema tersebut utamanya membahas mengenai beberapa pertanyaan kepada komponis tentang berbagai persoalan komposisi dan hal-hal yang berhubungan dengan filosofi kehidupan dan proses berkarya. Pertanyaan-pertanyaan tersebut meliputi: 1) Wie wird man Komponist?/Bagaimana orang bisa menjadi komponis?; 2) Was ist für einen Komponisten heute wichtig?/Apa yang dianggap penting oleh komponis sekarang ini?; 3) Kann man vom Komponieren leben?l Apakah seseorang bisa hidup dari komposisi?; 4) Wie geht das eigentlich, das Komponieren?/Apakah sebenarnya yang disebut membuat komposisi? Dialog semacam ini cukup penting untuk melengkapi bahan-bahan usulan mengenai konsep pelajaran musik kontemporer di kelas.

\section{Penutup}

Berdasarkan hasil analisis materi musik kontemporer dalam kurikulum dan buku sekolah di Jerman, maka terdapat hal-hal menarik yang kiranya patut dipertimbangkan kelayakannya untuk diterapkan di Indonesia. Beberapa contoh yang bisa dikemukakan di sini, misalnya siswa dikenalkan terlebih dahulu kepada hal-hal dasar mengenai bunyi untuk kemudian pengalaman ini digunakan sebagai bahan mempelajari musik, baik musik tradisi maupun kontemporer. Selain ini melalui musik kontemporer siswa diajak untuk memahami prinsip-prinsip dalam komposisi, di mana pengalaman praktek melalui bunyi dikenalkan terlebih dahulu, untuk selanjutnya pengalaman tersebut dijadikan landasan untuk memahami konteks musik di masyarakat.

Selain itu dalam konteks musik kontemporer dalam buku sekolah, kiranya yang bisa menjadi salah satu tawaran bagi desain buku pelajaran musik di Indonesia adalah materi bahan ajar sebaiknya selalu bertolak dari karya musik. Melalui karya musik inilah bisa ditarik berbagai tema-tema musikal yang bisa menjadi pokok bahasan pelajaran musik di kelas.

\section{Ucapan Terima Kasih}

Penulis menghaturkan terima kasih kepada Prof. Dr. Georg Maas dari Universitas Halle dan Prof. Dieter Mack dari Universitas Musik Luebeck yang sudah berkenan membimbing. Ucapan terima kasih juga disampaikan kepada DAAD (Dinas Pertukaran Akademis Jerman) yang sudah memberikan beasiswa untuk men-support kegiatan penelitian ini.

\section{Kepustakaan}

Becker, Peter. dkk. 1984. Spielpläne 5/6. Stuttgart: Ernst Klett Verlag.

Behrendt, Wilfried dan Bernhard Streerath. 1998. Dreiklang 7/8. Berlin: Volk und Wissen Verlag.

Detterbeck, Schmidt-Oberländer, Gero. 2011. Musixx. Das Kursbuch Musik 1. Esslingen: Helbling Verlag.

Gies, Stefan. 2005. Dreiklang 9/10. Volk und Wissen: Verlag GmbH \& Co.

Kemmelmeyer, Karl-Jürgen dan Rudolf Nykrin. 1997. Spielpläne 7/8. Stuttgart:: Ernst Klett 
Verlag.

Prinz, Ulrich; Scheytt, Albrecht. 2002. Musik um uns 2/3 Baden-Württemberg. Hannover: Schroedel Verlag.

Pütz, Werner dan Rainer Schmitt.1997. Hauptsache Musik 9/10. Stuttgart: Ernst Klett Verlag. Sachsen, Anhalt Kultusministerium des Landes.
2003. Rahmenrichtlinien Gymnasium Musik Schuljahrgänge 5-12. Magdeburg: Schroedel Verlag

Warsana. 2012. “Tumpang Tindih: Sebuah Komposisi Musik Dalam Interpretasi Personal” dalam Resital Jurnal Seni Pertunjukan, Vol. 13 No. 1 Juni 2012. 